\title{
Soil compaction caused by harvest and logging operations in eucalyptus forests in coarse-textured soils from northeastern Brazil
}

\section{Compactação do solo causada por operações de colheita e baldeio em florestas de eucalipto em solos de textura grosseira do nordeste do Brasil}

\author{
Maria Luiza de Carvalho Andrade ${ }^{1 *}$, Diego Tassinari' ${ }^{1}$ Moacir de Souza Dias Junior ${ }^{1}$, \\ Ricardo Previdente Martins ${ }^{2}$, Wellington Willian Rocha ${ }^{3}$, Zélio Resende de Souza ${ }^{1}$
}

\author{
${ }^{1}$ Universidade Federal de Lavras/UFLA, Departamento de Ciência do Solo/DCS, Lavras, MG, Brasil \\ ${ }^{2}$ Copener Florestal, Alagoinhas, BA, Brasil \\ ${ }^{3}$ Universidade Federal dos Vales do Jequitinhonha e Mucuri/UFVJM, Departamento de Agronomia, Diamantina, MG, Brasil \\ *Corresponding author: marialuizaandrade@dma.ufla.br \\ Received in September 9, 2016 and approved in December 5, 2016
}

\begin{abstract}
Planted forests occupy more than 6.5 million ha in Brazil, where harvest and logging operations are performed with increasingly heavier machinery, increasing the risk of soil compaction. Soil compaction can be avoided if soil load bearing capacity is not exceeded, what makes it important to assess both the soil strength and the impact of different operations. The aim of this study was to evaluate the load bearing capacity of some coarse textured soils (two Hapludult and one Haplorthod) in two soil horizons (BA and B), from northeastern Brazil; and to assess the impact of harvest and logging operations performed with harvester and forwarder. Although the Haplorthod presented higher load bearing capacity in both the BA horizon (for the whole moisture range) and the B horizon (for higher water contents), it suffered the greatest soil compaction. Traffic with the harvester resulted in soil compaction in both the BA and the B horizons, but the increase in bulk density was higher on the later, reaching $18.7 \%$ in the Haplorthod. The forwarder traffic intensity and the presence of plant residue cover significantly affected the occurrence of soil compaction. In the BA horizon, the increase in soil bulk density for different forwarder traffic intensities was 3 passes $\sim 6$ passes $<12$ passes $\sim 16$ passes. The increase in bulk density was higher in the Haplorthod, reaching 32\% after 16 forwarder passes over bare soil. Significant linear regressions were obtained from the number of forwarder passes and the increase in bulk density.
\end{abstract}

Index terms: Harvester; forwarder; precompression stress; soil load bearing capacity.

\begin{abstract}
RESUMO
As florestas plantadas ocupam mais de 6,5 milhões de ha no Brasil, nas quais as operações de colheita e baldeio são realizadas com maquinário cada vez mais robusto, o que aumenta o risco de compactação do solo. A compactação do solo pode ser evitada se a sua capacidade de suporte de carga não for excedida, o que torna importante a avaliação tanto da resistência mecânica do solo quanto o impacto de diferentes operações. $O$ objetivo deste estudo foi avaliar a capacidade de suporte de carga de solos de textura grosseira (dois Hapludult e um Haplorthod) em dois horizontes (BA e B) do Nordeste do Brasil; além de avaliar o impacto das operações de colheita e baldeio de madeira realizadas com harvester e forwarder. Apesar de o Haplorthod ter apresentado a maior capacidade de suporte de carga no horizonte BA (para toda a faixa de umidade) e no horizonte B (para maiores umidades) ele foi a classe de solo que apresentou maior compactação. O tráfego com o harvester resultou em compactação tanto no horizonte BA quanto no B, mas o aumento da densidade do solo foi maior no último, chegando a $18,7 \%$ no Haplorthod. A intensidade de tráfego do forwarder e a presença de resíduos de plantas na superfície do solo afetaram significativamente a ocorrência de compactação do solo. No horizonte BA, o aumento da densidade do solo em decorrência da intensidade de tráfego do forwarder foi de 3 passadas $\sim 6$ passadas $<12$ passadas $\sim 16$ passadas. 0 aumento de densidade do solo foi maior no Haplorthod, atingindo 32\% após 16 passadas sobre o solo descoberto. Regressões lineares significativas foram obtidas a partir do número de passadas do forwarder e o aumento na densidade do solo.
\end{abstract}

Termos para indexação: Harvester; forwarder; pressão de pré-consolidação; capacidade de suporte de carga do solo.

\section{INTRODUCTION}

In 2012, Brazil consumed approximately 182.5 million $\mathrm{m}^{3}$ of wood for industrial purposes, obtained from a total of 6.66 million ha of planted forests, from which about $35.2 \%$ was destined to wood pulp and paper production (Associação Brasileira de Produtores de Florestas Plantadas
- ABRAF, 2013). In 2014, Brazil produced over 16.8 million t of wood pulp ( $9.7 \%$ of world total production), ranking as third in world production and as first in wood pulp exports (Food and Agriculture Organization - FAO, 2015). Sustainable management practices and technological advances have been employed by large Brazilian forestry companies in order to 
achieve high yields from planted forests and to minimize environmental impacts which may compromise forest productivity, what can be seen in the projected investment rates for the period 2013-2017: from a total of R $\$ 6$ billion to be invested, $40.9 \%$ will be spent in planting activities and $12.3 \%$ in harvest and transport operations (ABRAF, 2013).

In forestry production, wood harvest in extensive areas demands the use of increasingly larger and heavier farm machinery (Silva; Dias Junior; Leite, 2010; Suzuki et al., 2014), which can exert elevated pressures upon the soil (Horn; Vossbrink; Becker, 2004; Martins et al., 2013). This sort of farm machinery may cause changes in soil physical and mechanical properties, resulting in soil compaction and soil structure degradation (Dias Junior et al., 2005; Dias Junior et al., 2008; Ampoorter et al., 2010). Therefore, if both high yields and environmental preservation are aimed in forestry production, it is essential that soil structure remains in good conditions (Cambi et al., 2015).

Soil precompression stress may be defined as the maximum pressure that a given soil has endured in the past (Koolen; Kuipers, 1983; Horn; Lebert, 1994). It has been used as an indicator of the soil mechanical strength and load bearing capacity to estimate more accurately the risk of soil compaction in various studies regarding forest harvest operations (Dias Junior et al., 2008, 2007; Martins et al., 2013; Silva; Dias Junior; Leite, 2010). Soil precompression stress and hence soil load bearing capacity decrease exponentially with increase in soil moisture (Lima et al., 2006; Mosaddeghi et al., 2006; Dias Junior et al., 2007; Ajayi et al., 2013); making these soil properties specially relevant in management strategies aiming to minimize the risk of additional soil compaction caused by traffic with farm machinery (Dias Junior et al., 2005; Pais et al., 2013; Severiano et al., 2013).

Several factors affect soil compaction in eucalypt forests, such as soil type and soil horizon/layer (Dias Junior et al., 2007); climatic season and, also related, soil moisture (Dias Junior et al., 2005); machinery kind (Dias Junior et al., 2007, 2005; Lopes et al., 2015); traffic intensity (Dias Junior et al., 2008; Martins et al., 2013; Pezzoni Filho et al., 2014); machinery load (Silva; Dias Junior; Leite, 2011); and soil cover (Silva; Dias Junior; Leite, 2007, 2010; Szymczak et al., 2014). It is, therefore, fundamental to understand how machinery traffic during harvest and logging operations in forestry production affects soil load bearing capacity and the occurrence of soil compaction, especially when mechanized operations are performed on excessively moist conditions (Dias Junior et al., 2005; Kamimura et al., 2012; Vischi Filho et al., 2015), aiming to adapt management practices in order to preserve soil structure and forests yield potential. In this sense, Dias Junior et al. (2005) presented a strategy that has been used for quantifying the amount of compaction after farm machinery traffic regarding the changes in soil mechanical strength, which can be seen in Figure 1. The criteria used for determining the impact of mechanized operations on soil structure is based on plotting the ordinate pairs precompression stress, soil moisture (obtained from samples after mechanized operations) on the soil load bearing capacity model (obtained before mechanized operations). Three regions can be identified as shown in Figure 1, (a) one above the prediction band superior limit, in which soil compaction (characterized by an increase in soil strength) has already occurred; (b) another region between the prediction bands, where soil compaction has not yet occurred but may take place during the following operations if the pressures applied are greater than those defined by the prediction band superior limit; and (c) one region below the lower prediction band, where soil compaction has not occurred at all.

This study aimed to (i) obtain the load bearing capacity models, which relate the decrease in precompression stress with increase in soil moisture, for different coarsetextured soils planted with eucalypt (Eucalyptus sp.) forests; (ii) determine the impacts on soil structure of harvest and logging operations performed with harvester and forwarder; (iii) quantify the effects of the number of forwarder passes and the presence of plant residue cover on the soil surface in the occurrence of soil compaction.

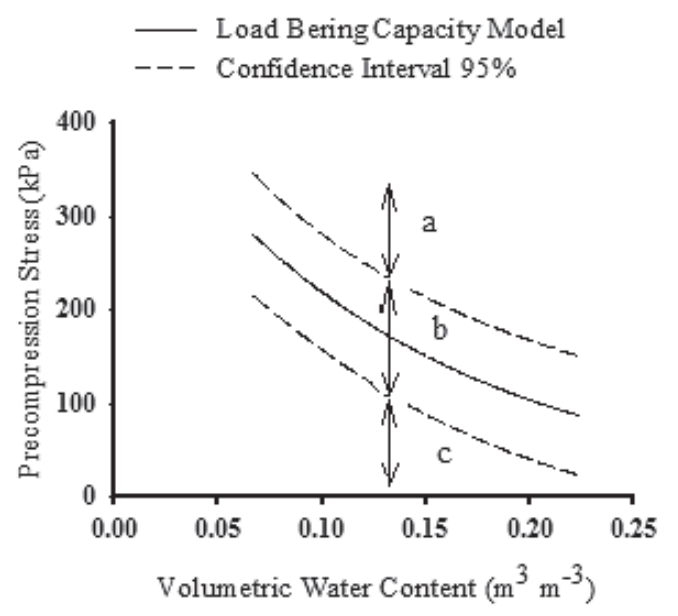

Figure 1: Criteria for determining the impact of mechanized operations on soil structure according to Dias Junior et al. (2005). The letters " $a$ ", "b" and "c" indicate the regions where: (a) soil compaction has already occurred; (b) soil compaction has not yet occurred, but may take place during the following operations if the pressures applied are greater than those defined by the prediction band superior limit; and (c) soil compaction has not occurred at all. 


\section{MATERIAL AND METHODS}

This study was carried out during harvest operations in selected areas from commercial forests planted with eucalypt (Eucalyptus sp.). The forests belong to Suzano Papel e Celulose Co. and are located in the Teixeira de Freitas county, Bahia State, Northeastern Brazil, with coordinates $17^{\circ} 32^{\prime} 27^{\prime \prime} \mathrm{S}$ and $39^{\circ} 44^{\prime} 25^{\prime \prime} \mathrm{W}$ and an average altitude of $624 \mathrm{~m}$. On the most southern extreme from Bahia State, mean annual rainfall is about $1,100 \mathrm{~mm}$ and temperature averages range between 23 and $27^{\circ} \mathrm{C}$.

Three different soils were sampled, two Hapludult (termed Hapludult-1 and Hapludult-2) and one Haplorthod according to Soil Taxonomy (Soil Survey Staff, 1999), which in the Brazilian Soil Classification System are classified as Dystrocohesive Yellow Argisol and Orthic Ferriluvic Spodosol respectively (Santos et al., 2013a). Undisturbed soil samples (collected in metal rings with 6.4 $\mathrm{cm}$ diameter and $2.5 \mathrm{~cm}$ height) were taken from the BA and the upper B horizon in each soil, which were chosen after an investigation in soil profiles and were perceived as the soil layers with the highest mechanical resistance to manual inspection with a knife. Samples were collected with an Uhland sampler, wrapped in plastic film and covered with paraffin in the field preserve structure and moisture. The exceeding soil from the core samples was air dried, sieved $(2.0 \mathrm{~mm})$ and used on textural (Gee; Bauder, 1986) and particle density (Blake; Hartge, 1986) analysis, from which the results can be seen in Table 1. Soil dispersion for textural analysis was accomplished with $1.0 \mathrm{M} \mathrm{NaOH}$ and $16 \mathrm{~h}$ shaking at $30 \mathrm{rpm}$, after what the suspension was passed on a $53 \mu \mathrm{m}$ opening sieve and allowed to rest for decantation of silt particles. Particle density was determined on volumetric flasks filled with ethanol.
To characterize the mechanical strength of each soil and horizon, 15 undisturbed soil samples, randomly distributed in the field, were taken from the upper portion of both the BA $(0.10-0.13 \mathrm{~m})$ and the $\mathrm{B}(0.45-0.48 \mathrm{~m})$ horizons in each soil class prior to harvest operations, resulting in 90 samples ( 3 soil classes x 2 horizons x 15 samples). To obtain the load bearing capacity models, the undisturbed soil samples were saturated and/or allowed to air dry in the laboratory prior to the uniaxial compression tests, in order to simulate a broad range of water contents (mostly ranging from 0.05 to $0.35 \mathrm{~m}^{3} \mathrm{~m}^{-3}$ ).

The harvest system classifies as cut-to-length, in which trees are felled, delimbed and bucked with a harvester (vehicle: excavator model 200C LC John Deer ${ }^{\circledR}$; harvesting head: model $370 \mathrm{E}$ Valmet $^{\mathbb{R}}$ ) and logs are transported with a forwarder (model 1710 John Deer ${ }^{\circledR}$ ). To evaluate the soil compaction caused by the harvester, 15 undisturbed samples randomly distributed in the field were taken from each soil class and horizon after traffic with the harvester, resulting in 90 samples (15 samples x 3 soil classes x 2 horizons). The compaction caused by the forwarder was assessed considering different conditions: the presence or absence of plant residue over the soil surface and the number of passes (each pass comprises a travel forward and backward). When soil surface was covered with plant residue, 3 samples were taken after 3, 6, 12 and 16 passes with the forwarder in each soil class and horizon, resulting in 72 samples ( 3 soil classes x 2 horizons x 4 number of passes x 3 samples). In the absence of plant residue on the soil surface, 2 samples were taken after 3,6,12 and 16 passes with the forwarder in each soil class and horizon, resulting in 48 samples ( 3 soil classes $\mathrm{x} 2$ horizons $\mathrm{x} 4$ numbers of passes $\mathrm{x} 2$ samples). These soil samples were also submitted to uniaxial compression tests, but unlike the aforementioned samples, they were tested with the actual field moisture.

Table 1: Soil texture (clay, silt and sand contents) and particle density $\left(\rho_{s}\right)$ from the evaluated soils and horizons under eucalypt forests in Teixeira de Freitas-BA, northeastern Brazil.

\begin{tabular}{|c|c|c|c|c|c|c|}
\hline Soil class & Horizon & $\begin{array}{c}\rho_{s} \\
M g ~ m^{-3}\end{array}$ & $\begin{array}{c}\text { Clay } \\
\text {---- }\end{array}$ & $\begin{array}{c}\text { Silt } \\
\mathrm{g} \mathrm{kg}^{-1}\end{array}$ & $\begin{array}{l}\text { Sand } \\
-----\end{array}$ & Textural class ${ }^{1}$ \\
\hline \multirow{2}{*}{ Hapludult-1 } & $\mathrm{BA}$ & 2.57 & 170 & 10 & 820 & Sandy loam \\
\hline & $\mathrm{Bt}$ & 2.57 & 290 & 50 & 660 & Sandy clay loam \\
\hline \multirow{2}{*}{ Hapludult-2 } & BA & 2.56 & 120 & 20 & 860 & Loamy sand \\
\hline & $\mathrm{Bt}$ & 2.57 & 200 & 30 & 770 & Sandy clay loam \\
\hline \multirow{2}{*}{ Haplorthod } & BA & 2.60 & 60 & 20 & 920 & Sandy \\
\hline & Bts & 2.58 & 220 & 40 & 740 & Sandy clay loam \\
\hline
\end{tabular}

${ }^{1}$ According to Santos et al. (2013b). 
The undisturbed soil samples were submitted to confined drained uniaxial compression tests on compressedair consolidometers (Terraload S-450, Durham GeoSlope ${ }^{\circledR}$ ). In this test, only the normal stress is applied and the rigid cylinder wall that contains the sample prevents lateral displacement and shearing. Additionally, porous stones above and beneath the sample allowed for drainage, preventing pore water pressures from rising (thus the applied pressure is approximately equal to the effective stress). Pressures of $25,50,100,200,400,800$ and $1,600 \mathrm{kPa}$ (standard sequence according to Bowles, 1986) were applied until at least 90\% of maximum deformation was reached (Taylor, 1948) in sequence and without decompression. Soil displacement during compression was recorded and precompression stress values were determined according to the procedure from Dias Junior and Pierce (1995). Precompression stress and water content values were adjusted to the equation $\sigma_{\mathrm{p}}=10^{(\mathrm{a}+\mathrm{b} \theta)}$ (Dias Junior et al., 2005) which defines the load bearing capacity model, where $\sigma_{\mathrm{p}}$ is the precompression stress, $\theta$ is the volumetric water content and "a" and "b" are the adjusted parameters. The resultant models were compared to each other according to the procedure from Snedecor and Cochran (1989) for comparison between linear regressions.

Precompression stress and water content values from the samples collected after traffic with the harvester and the forwarder were then plotted on the load bearing capacity models (obtained prior to mechanized operations) to determine the amount of compacted soil samples according to the criteria from Dias Junior et al. (2005), which can be seen in Figure 1.

\section{RESULTS AND DISCUSSION}

\section{Load bearing capacity models}

The resultant load bearing capacity models can be seen in Figure 2. The equations for the load bearing capacity models from the different soil classes and horizons were compared to each other (Table 2). In the BA horizon, all models significantly differed from each other, while on the $B$ horizon the models from Hapludult-1 and Hapludult-2 did not differ significantly and were further merged into a single model (Figure 2). The $\mathrm{R}^{2}$ values varied from 0.89 to 0.96 , indicating very good fit, and the regressions were all significant at $1 \%$. The " $\mathrm{a}$ " and "b" regression adjustment parameters varied, respectively, from 2.62 to 2.67 and from -1.88 to -3.14 in the BA horizon; and in the B horizon from 2.74 to 2.97 and from -2.17 to -4.14 . The slightly higher values for the "a" parameter in the B horizon may indicate higher load bearing capacity, as this parameter is related to the position of the curve on the ordinate axis. The higher values (in modulus) for the "b" parameter in this horizon indicate a higher rate of decrease in precompression stress with the increase in water content. These differences may be related to the higher clay contents in the B horizons in comparison to the BA horizons.
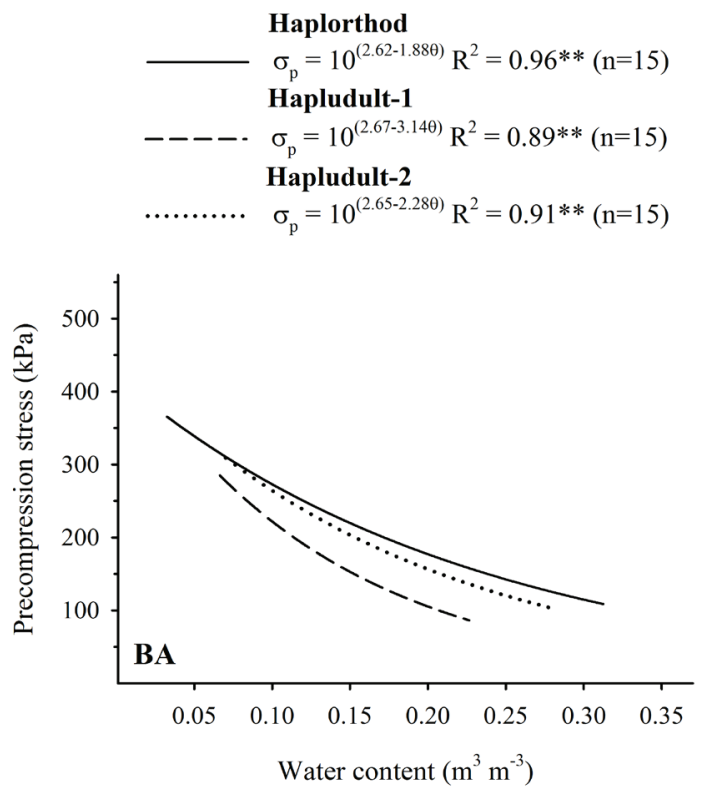
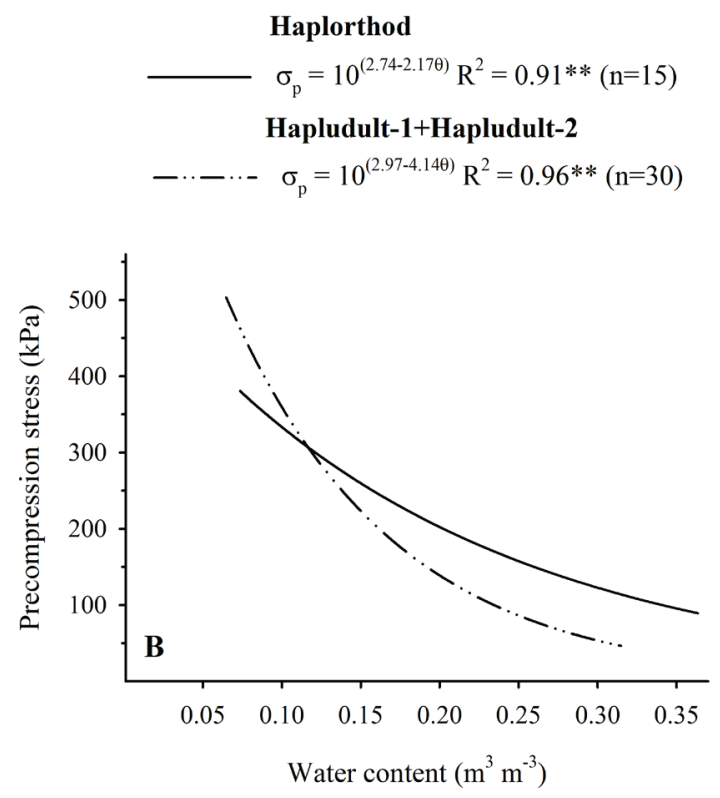

Figure 2: Load bearing capacity models obtained for the different soil classes and soil horizons under eucalypt forests from Teixeira de Freitas-BA, northeastern Brazil. 
Table 2: Comparison of the load bearing capacity models according to the test from Snedecor and Cochran (1989) for different soil classes and horizons under eucalypt forests from Teixeira de Freitas-BA, northeastern Brazil.

\begin{tabular}{|c|c|c|c|}
\hline \multirow{2}{*}{ Comparison between soil classes } & \multirow{2}{*}{ Homogeneity test } & \multicolumn{2}{|c|}{ Test results } \\
\hline & & "b" parameter & "a" parameter \\
\hline & \multicolumn{3}{|c|}{ BA horizon } \\
\hline Hapludult-1 x Haplorthod & $\mathrm{H}$ & $\star \star$ & ** \\
\hline Hapludult-2 x Hapludult-1 & $\mathrm{H}$ & * & $\star \star$ \\
\hline \multirow[t]{2}{*}{ Hapludult-2 x Haplorthod } & $\mathrm{H}$ & Ns & * \\
\hline & \multicolumn{3}{|c|}{ B horizon } \\
\hline Hapludult-2 x Hapludult-1 & $\mathrm{H}$ & Ns & Ns \\
\hline $\begin{array}{l}\text { Hapludult-2+Hapludult-1 x } \\
\text { Haplorthod }\end{array}$ & $\mathrm{H}$ & $\star \star$ & $\star \star$ \\
\hline
\end{tabular}

$\mathrm{H}$ : homogenous; **: significant at 1\%; *: significant at 5\%; Ns: Non-significant.

In the BA horizon, the Haplorthod presented higher load bearing capacity throughout the whole moisture range. In the B horizon, Hapludult-1 and Hapludult-2 (represented by a single model) presented higher load bearing capacity when dry, but, as they also presented a higher rate of decrease in precompression stress with increase in moisture, the Haplorthod presented higher load bearing capacity for higher water contents (above $0.12 \mathrm{~m}^{3} \mathrm{~m}^{-3}$ ).

\section{Soil compaction caused by harvester's traffic}

In the BA horizon, traffic with the harvester resulted in a higher proportion of compacted samples (Table 3) in Hapludult-1 and Haplorthod (47\% for both), even though the Haplorthod presented the higher load bearing capacity in this horizon (Figure 2). On the surface horizon of different coarse textured Ultisols, Dias Junior et al. (2008) observed that the proportion of compacted samples ranged from $17 \%$ to $83 \%$ after the passage of a harvester, but the overall average was around $52 \%$, close to our results. Additionally, the Haplorthod also suffered the greatest increase in soil bulk density (5.2\%) in this horizon (Table 3), whilst Hapludult-1 and Hapludult-2 showed no increase in bulk density at all. The higher sand content in the BA horizon of the Haplorthod and the resulting single grain structure favor the packing of sand particles into the soil voids upon the application of an external force (Mantovani, 1987; Dias Junior; Miranda, 2000). Because of its lack of cohesion, sandy soils are especially prone to compaction by repeated loading or vibration (Koolen; Kuipers, 1983), a situation that may happen in the field but that was not repeated in the uniaxial compression tests. For the BA horizon in Hapludult-1 and Hapludult-2, the number of compacted samples varied accordingly to the load bearing capacity models, with the most resistant soil portraying fewer compacted samples.

In the B horizon, the Haplorthod presented again the higher amount of compacted samples $(47 \%)$, whereas Hapludult-1 and Hapludult-2 presented 33\% and 27\% of compacted samples respectively. Although differences in samples average moisture were non-significant (Table 3), the aforementioned results may be due to some slight differences in water content by the time of traffic, as can be seen in the boxplots in Figure 3. During traffic with the harvester, the majority of soils presented a greater proportion of samples with a moisture content below $0.12 \mathrm{~m}^{3} \mathrm{~m}^{-3}$ (as can be seen from the position of the median usually below the mean), and in this moisture range the Haplorthod expresses lower bearing capacity than the other soils (Figure 2).

The occurrence of compacted soil samples was higher in the BA than in the B horizon, however, bulk density increase was significantly higher in the $\mathrm{B}$ horizon for the Hapludult-2 and the Haplorthod in comparison to the BA horizon. Higher compaction in the surface layer was observed by Dias Junior et al. (2005) after passage of a harvester on sandy loam/sandy clay loam (A/B horizon respectively) Ultisol, with $44 \%$ and $0 \%$ of compacted samples in the $0.0-0.03$ and $0.35-0.38 \mathrm{~m}$ soil layers respectively and bulk density increase of $14.5 \%$ and 3.3\%. On a sandy Podzol, Ampoorter et al. (2007) reported increases in soil bulk density on the harvester traffic line of $8.2,8.7$ and $7.1 \%$ in the $0.0-0.10,0.10-0.20$ and $0.20-0.30 \mathrm{~m}$ soil layers respectively, much lower than what was observed in the B horizon from the Haplorthod. 
Table 3: Bulk density values before harvest operations $\left(\rho_{\mathrm{bi}}\right)$ and after traffic with the harvester $\left(\rho_{\mathrm{b}}\right)$ and the resulting change in bulk density, proportion of compacted samples after the harvester passage and average soil water content during traffic $(\theta)$ on the different soil classes and horizons under eucalypt forests from Teixeira de Freitas-BA, northeastern Brazil.

\begin{tabular}{cccccc}
\hline Soil class & $\begin{array}{c}\rho_{\mathrm{bi}} \\
\left(\mathrm{Mg} \mathrm{m}^{-3}\right)\end{array}$ & $\begin{array}{c}\rho_{\mathrm{b}} \\
\left(\mathrm{Mg} \mathrm{m}^{-3}\right)\end{array}$ & $\begin{array}{c}\text { Change in bulk } \\
\text { density } \\
(\%)\end{array}$ & $\begin{array}{c}\text { Compacted samples } \\
(\%)\end{array}$ & $\begin{array}{c}\theta^{\text {ns }} \\
\left(\mathrm{m}^{3} \mathrm{~m}^{-3}\right)\end{array}$ \\
\hline & \multicolumn{5}{c}{ BA horizon } \\
Hapludult-1 & 1.58 & $1.58 \mathrm{Aa}$ & $0.0 \mathrm{Ba}$ & 47 \\
Hapludult-2 & 1.55 & $1.54 \mathrm{Ba}$ & $-0.9 \mathrm{Bb}$ & 33 & 0.113 \\
Haplorthod & 1.53 & $1.61 \mathrm{Aa}$ & $5.2 \mathrm{Ab}$ & 47 & 0.095 \\
\hline & \multicolumn{5}{c}{$\mathrm{B}$ horizon } \\
Hapludult-1 & 1.46 & $1.46 \mathrm{Bb}$ & $0.0 \mathrm{Ca}$ & 33 \\
Hapludult-2 & 1.40 & $1.50 \mathrm{Ba}$ & 7.0Ba & 27 & 0.128 \\
Haplorthod & 1.39 & $1.65 \mathrm{Aa}$ & $18.7 \mathrm{Aa}$ & 47 & 0.122 \\
\hline
\end{tabular}

${ }^{1}$ according to the criteria from Dias Junior et al. (2005) shown in Figure 1. ns: non-significant in the analysis of variance. Means followed by the same letter do not differ from each other by the Scott-Knott test at 5\% significance. Capital letters compare soil classes within the same horizon and small letters compare horizons within each soil class.

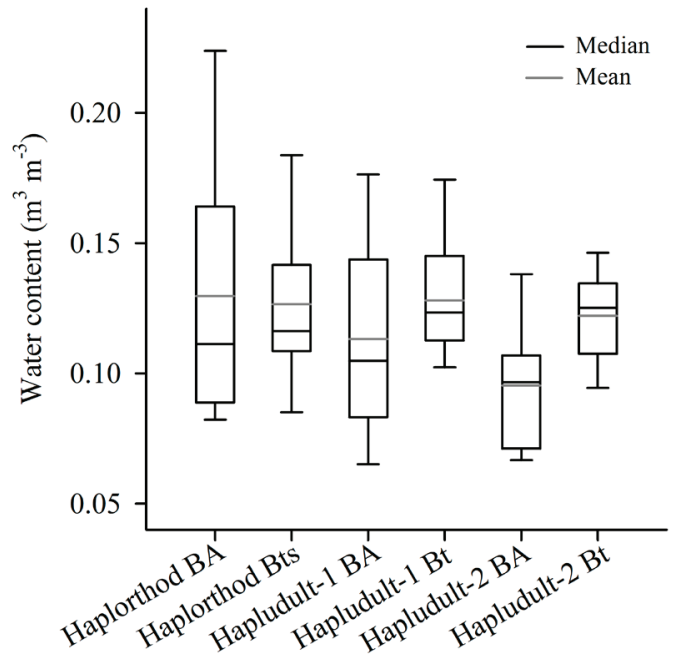

Figure 3: Boxplot for soil water content from the samples collected after traffic with the harvester in different soil classes and horizons under eucalypt forests from Teixeira de Freitas-BA, northeastern Brazil.

\section{Soil compaction caused by forwarder's traffic}

The number of compacted samples was affected by forwarder traffic intensity, plant residue cover on the soil surface, and soil class (Table 4). In the BA horizon, the Hapludults presented fewer compacted samples than the Haplorthod, which portrayed additional compaction in all samples from every traffic intensity on both bare soil and over plant residue. The previous discussion regarding traffic with the harvester also applies here, but in this case the differences in water content between soil classes during traffic with the forwarder were much higher (Figure 4), with the Haplorthod presenting higher water contents during field traffic. The increase in bulk density in the BA horizon followed Haplorthod $>$ Hapludult-2 $>$ Hapludult-1 (Table 5), what is in accordance with the load bearing capacity models (Figure 2 ). In the B horizon, the Haplorthod also suffered the greatest increase in bulk density, while the results for the Hapludults presented some inconsistencies (Table 5). The several negative values may be related to the spatial variation in the depth of the horizons (as the sampling depth was fixed) and in clay contents. This variation could result in textural variation within the samples, what would affect bulk density values.

The number of compacted samples did not differ much between horizons (Table 4), although higher compaction is usually noticed in the most shallow layers (Ampoorter et al., 2007; Dias Junior et al., 2007; Dias Junior et al., 2008). The upper BA horizon in these soils often presents a high mechanical strength and may become more severely hampered by additional compaction. This soil layer stands in a shallower position in relation to the $\mathrm{B}$ horizon and therefore endures greater pressures; and is naturally more impeding to root growth than the layers above it, constantly loosened because of higher organic matter content and biological activity. 
Table 4: Percentage of compacted samples on different soils, horizons, and soil surface conditions according to the criteria from figure 1 (Dias Junior et al., 2005) after several forwarder traffic intensities in eucalypt forests from Teixeira de Freitas-BA, northeastern Brazil.

\begin{tabular}{|c|c|c|c|c|c|}
\hline \multirow{2}{*}{ Soil class } & \multirow{2}{*}{ Soil surface } & \multicolumn{4}{|c|}{ Forwarder traffic intensity } \\
\hline & & 3 passes & 6 passes & 12 passes & 16 passes \\
\hline & & \multicolumn{4}{|c|}{ BA horizon } \\
\hline \multirow{2}{*}{ Hapludult-1 } & bare soil & 67 & 67 & 100 & 100 \\
\hline & residue cover & 0 & 0 & 50 & 100 \\
\hline \multirow{2}{*}{ Hapludult-2 } & bare soil & 67 & 67 & 100 & 100 \\
\hline & residue cover & 0 & 50 & 100 & 100 \\
\hline \multirow{3}{*}{ Haplorthod } & bare soil & 100 & 100 & 100 & 100 \\
\hline & residue cover & 100 & 100 & 100 & 100 \\
\hline & & \multicolumn{4}{|c|}{ B horizon } \\
\hline \multirow{2}{*}{ Hapludult-1 } & bare soil & 67 & 67 & 67 & 100 \\
\hline & residue cover & 0 & 0 & 0 & 100 \\
\hline \multirow{2}{*}{ Hapludult-2 } & bare soil & 67 & 100 & 100 & 100 \\
\hline & residue cover & 50 & 50 & 50 & 100 \\
\hline \multirow{2}{*}{ Haplorthod } & bare soil & 100 & 100 & 100 & 100 \\
\hline & residue cover & 100 & 50 & 50 & 50 \\
\hline
\end{tabular}

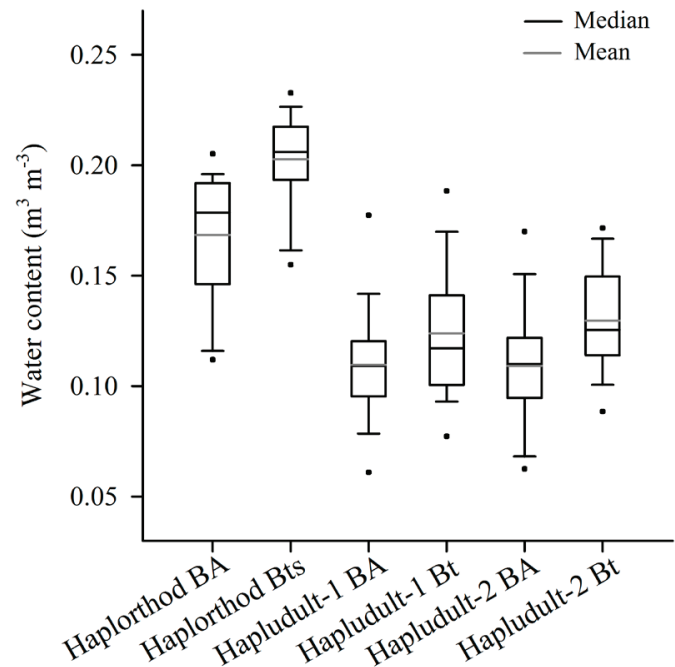

Figure 4: Boxplot for soil water content from the samples collected after traffic with the forwarder in different soil classes and horizons under eucalypt forests from Teixeira de Freitas-BA, northeastern Brazil.

The plant residue on the soil surface was effective in preventing compaction in the BA horizon only in the Hapludults up to 6 passes, while in the Haplorthod additional compaction was observed on all samples regardless of traffic intensity and soil surface condition (Table 4). In the B horizon, the number of compacted samples also decreased when the soil was covered with plant residues during traffic. Also the increase in bulk density was higher when soil was trafficked bare in comparison to the soil trafficked with residue cover (Table 5), as expected and in accordance with several other studies (Martins et al., 2013; Silva; Dias Junior; Leite, 2010).

After 12 and 16 passes with the forwarder, additional compaction was observed on nearly all samples from the BA horizon, regardless of soil surface condition (Table 4). In this soil layer, the increase in soil bulk density was, according to the number of passes, $3 \sim 6<12 \sim 16$ (Table 5). This observation is in accordance with Dias Junior et al. (2008), which concluded that eight passes of a forwarder could be adopted as a critical limit for this equipment traffic intensity in two coarse-textured Ultisols, from which one on the traffic ruts formed and the increase in bulk density indicated severe soil compaction.

Traffic intensity was further investigated as a continuous variable through fitting the number of forwarder passes as the independent variable to a linear equation with the increase in soil bulk density as the dependent variable. Linear regressions between traffic intensity and the increase in soil bulk density were only significant for traffic over bare soil in the Haplorthod (in both the BA and the Bts horizons) and the Hapludult-2 (only in the BA horizon), as can be seen in Table 6 . 
Table 5: Change in soil bulk density on different soils, horizons and soil surface conditions after several forwarder traffic intensities in eucalypt forests from Teixeira de Freitas-BA, northeastern Brazil.

\begin{tabular}{|c|c|c|c|c|c|}
\hline \multirow{2}{*}{ Soil class } & \multirow{2}{*}{ Soil surface } & \multicolumn{4}{|c|}{ Forwarder traffic intensity } \\
\hline & & 3 passes & 6 passes & 12 passes & 16 passes \\
\hline & & \multicolumn{4}{|c|}{ BA horizon } \\
\hline \multirow{2}{*}{ Hapludult-1 } & bare soil & $-1.2 \mathrm{Caa}$ & $1.8 \mathrm{Caa}$ & $3.5 \mathrm{Ca} \beta$ & $0.3 \mathrm{Ca \beta}$ \\
\hline & residue cover & $-0.4 \mathrm{Cba}$ & $1.1 \mathrm{Cba}$ & $1.1 \mathrm{Cb} \beta$ & $1.4 \mathrm{Cb} \beta$ \\
\hline \multirow{2}{*}{ Hapludult-2 } & bare soil & 3.3Baa & 5.0Baa & $6.3 \mathrm{Ba} \beta$ & 11.4Baß \\
\hline & residue cover & $-2.9 \mathrm{Bba}$ & 3.8Bba & $-2.6 \mathrm{Bb} \beta$ & $7.7 \mathrm{Bb} \beta$ \\
\hline \multirow{3}{*}{ Haplorthod } & bare soil & 9.8Aaa & 13.5Aaa & 18.9Aaß & $19.6 \mathrm{Aa} \beta$ \\
\hline & residue cover & $8.8 \mathrm{Aba}$ & 7.2Aba & $12.7 \mathrm{Ab} \beta$ & $11.1 \mathrm{Ab} \beta$ \\
\hline & & \multicolumn{4}{|c|}{ B horizon } \\
\hline \multirow{2}{*}{ Hapludult-1 } & bare soil & $-4.6 \mathrm{C}$ & $-8.7 C$ & $-3.0 \mathrm{~B}$ & $-1.2 B$ \\
\hline & residue cover & $-1.9 \mathrm{~B}$ & $-1.2 \mathrm{~B}$ & $-0.2 B$ & $-5.0 \mathrm{C}$ \\
\hline \multirow{2}{*}{ Hapludult-2 } & bare soil & 9.9Baa & $-0.3 B \beta$ & $-7.2 \mathrm{By}$ & 3.3Ba \\
\hline & residue cover & $-0.4 \mathrm{Bb} \beta$ & $-4.0 B \beta$ & $-9.3 C \beta$ & $9.2 \mathrm{Ba}$ \\
\hline \multirow{2}{*}{ Haplorthod } & bare soil & $21.8 \mathrm{~A} \beta$ & $23.9 A \beta$ & $28.2 \mathrm{Aa}$ & 32.1Aaa \\
\hline & residue cover & $19.5 \mathrm{~A}$ & $29.2 \mathrm{~A}$ & $27.0 \mathrm{~A}$ & $22.0 \mathrm{Ab}$ \\
\hline
\end{tabular}

Capital letters compare soil classes, small letters compare soil surface condition and Greek letters compare traffic intensities. In the BA horizon interactions were non-significant. In the B horizon the third order interaction was significant. When letters are not shown, differences were non-significant in the nested analysis of variance.

Table 6: Significance level ( $P$ value) for the linear regressions fitted with the number of forwarder passes as the independent variable and the increase in soil bulk density as the dependent variable for different soil classes, horizons and surface conditions in eucalypt forests from Teixeira de Freitas-BA, northeastern Brazil.

\begin{tabular}{ccc}
\hline \multirow{2}{*}{ Soil class } & \multicolumn{2}{c}{ P value } \\
\cline { 2 - 3 } & \multicolumn{2}{c}{ BA } \\
\hline Haplorthod & $0.001^{* *}$ & $<0.001^{* *}$ \\
Hapludult-1 & $0.598^{\mathrm{ns}}$ & $0.265^{\mathrm{ns}}$ \\
Hapludult-2 & $0.035^{*}$ & $0.172^{\mathrm{ns}}$ \\
& \multicolumn{2}{c}{ Residue cover } \\
Haplorthod & $0.500^{\mathrm{ns}}$ & $0.884^{\mathrm{ns}}$ \\
Hapludult-1 & $0.349^{\mathrm{ns}}$ & $0.507^{\mathrm{ns}}$ \\
Hapludult-2 & $0.289^{\mathrm{ns}}$ & $0.376^{\mathrm{ns}}$ \\
\hline **: significant at 1\%. *: significant at 5\%. ${ }^{\mathrm{ns}}$ : Non-significant.
\end{tabular}

The lack of significant linear relations when the soil surface was covered with plant residue reinforces the effectiveness of this management practice in dissipating machinery induced pressures and reducing soil compaction since it was not observed a significant direct relation between the increase in the number of passes and the increase in soil compaction. The linear regressions (Table 7) for the Haplorthod indicated that the Bts horizon was more affected by the forwarder traffic than the BA horizon, as the intercept value for the former was more than the double of the later. The angular coefficients, however, were similar for both, indicating that compaction would increase in the same pace with the increase in traffic intensity for both horizons. The BA horizon from the Hapludult-2 presented a much smaller intercept value and the angular coefficient indicated an increment of $1 \%$ in soil bulk density for every 2 additional forwarder passes.

The Haplorthod repeatedly presented the higher amount of soil compaction throughout the entire study, and was also the soil which resulted in the most significant linear relations between the increase in bulk density and traffic intensity. During traffic with the forwarder, this soil class presented the higher water content (Figure 4), what explains why it suffered the most severe compaction. Nevertheless, it indicated that when soil is trafficked under excessively moist conditions, soil compaction increases linearly with increase in forwarder traffic intensity. 
Table 7: Linear regressions between soil compaction (x: increase in soil bulk density) and traffic intensity (y: number of forwarder passes) for the significant regressions from table 6.

\begin{tabular}{cr}
\hline Soil class and horizon & Linear regression \\
\hline Haplorthod BA & $y=8.3+0.77{ }^{*} x$ \\
Haplorthod Bts & $y=19.3+0.78{ }^{*} x$ \\
Hapludult-2 BA & $y=1.3+0.56{ }^{*} x$ \\
\hline
\end{tabular}

\section{CONCLUSIONS}

Soil load bearing capacity varied significantly between the evaluated soils. In the BA horizon, load bearing capacity followed Haplorthod $>$ Hapludult-2 $>$ Hapludult-1. In the B horizon, the Hapludults did not differ from each other and presented a higher rate of decrease in precompression stress with the increase in water content. Traffic with the harvester resulted in a higher compaction in the Haplorthod. Soil bulk density did not increase in the BA horizons from the Hapludults, but in the Haplorthod the increase in bulk density was $5.2 \%$ and $18.7 \%$ in the BA and Bts horizons, respectively. Traffic with the forwarder resulted in higher amount of compacted samples and greater increases in soil bulk density in comparison to the harvester. The Haplorthod was the soil that endured greater soil compaction caused by the forwarder. Forwarder traffic intensity and the presence of plant residue cover on the soil surface significantly affected the occurrence of soil compaction. The number of compacted samples and the increase in soil bulk density were higher when soil was trafficked bare. In the BA horizon, the increase in soil bulk density regarding forwarder traffic intensity was 3 passes $\sim 6$ passes $<12$ passes $\sim 16$ passes. The increase in bulk density was higher in the Haplorthod, reaching 32\% after 16 forwarder passes over bare soil. Significant linear regressions were obtained from the number of forwarder passes and the increase in bulk density for the Haplorthod and the Hapludult-2 (BA horizon).

\section{ACKNOWLEDGMENTS}

The authors would like to thank FAPEMIG, CNPq, Capes and Suzano Papel e Celulose, for funding the work.

\section{REFERENCES}

AJAYI, A. E. et al. Compressive response of some agricultural soils influenced by the mineralogy and moisture. International Agrophysics, 27:239-246, 2013.
ASSOCIAÇÃO BRASILEIRA DOS PRODUTORES DE FLORESTAS PLANTADAS - ABRAF. Anuário estatístico da ABRAF 2013 ano base 2012. Brasília: ABRAF, 2013. 148p.

AMPOORTER, E. et al. Impact of mechanized logging on compaction status of sandy forest soils. Forest Ecology Management, 241:162-174, 2007.

AMPOORTER, E. et al. Assessing the effects of initial soil characteristics, machine mass and traffic intensity on forest soil compaction. Forest Ecology Management, 260:1664-1676, 2010.

BLAKE, G. R.; HARTGE, K. H. Particle density. In: KLUTE, A. (ed). Methods of soil analysis. 2. ed. Madison, ASA/SSSA, 1986. Part 1, p.377-382.

BOWLES, J. E. Engineering properties of soils and their measurements. 3. ed. New York, McGraw Hill, 1986, 218p.

CAMBI, M. et al. The impact of heavy traffic on forest soils: A review. Forest Ecology Management, 338:124-138. 2015.

DIAS JUNIOR, M. S. et al. Traffic effects on the preconsolidation pressure due to eucalyptus harvest operations. Scientia Agricola, 62(3):248-255, 2005.

DIAS JUNIOR, M. S. et al. Soil compaction due to forest harvest operations. Pesquisa Agropecuária Brasileira, 42(2):257264, 2007.

DIAS JUNIOR, M. S. et al. Assessment of the soil compaction of two Ultisols caused by logging operations. Revista Brasileira de Ciência do Solo, 32:2245-2253, 2008.

DIASJUNIOR, M. S.; MIRANDA, E. E. V. Comportamento da curva de compactação de cinco solos da região de Lavras (MG). Ciência e Agrotecnologia, 24(2):337-346, 2000.

DIAS JUNIOR, M. S.; PIERCE, F. J. A simple procedure for estimating preconsolidation pressure from soil compression curves. Soil Technology, 8 (2):139-151, 1995.

FOOD AND AGRICULTURE ORGANIZATION - FAO. 2015. FAOSTAT

- Forestry Production and Trade. Available in: <http:// faostat3.fao.org/browse/F/*/E>. Access in: 5 Jun. 2016.

GEE, G. W.; BAUDER, J. W. Particle-size analysis. In: KLUTE, A. (ed.) Methods of soil analysis. Part 1. Physical and mineralogical methods. 2. ed. Madison, American Society of Agronomy, Soil Science Society of America, 1986. p.383411. (Agronomy Series, 9).

HORN, R.; LEBERT, M. Soil compactability and compressibility. In: SOANE, B. D.; van OUWERKERK, C. (Ed.). Soil Compaction in Crop Production. Amsterdam: Elsevier Science, 1994. p.45-69. 
HORN, R.; VOSSBRINK, J.; BECKER, S. Modern forestry vehicles and their impacts on soil physical properties. Soil \& Tillage Research, 79(2):207-219, 2004.

LIMA, C. L. R. et al. Estimativa da capacidade de suporte de carga do solo a partir da avaliação da resistência à penetração. Revista Brasileira de Ciência do Solo, 30:217-223, 2006.

KAMIMURA, K. M. et al. Capacidade de suporte de carga de um Latossolo Vermelho-Amarelo em uma lavoura cafeeira Revista Brasileira de Ciência do Solo, 36:1457-1465, 2012.

KOOLEN, A. J., KUIPERS, H. Agricultural Soil Mechanics. Berlin: Springer-Verlag, 1983, 241p.

LOPES, E. da S. et al. Compactação de um solo submetido ao tráfego do harvester e do forwarder na colheita de madeira. Flor@am - Floresta e Ambiente, 22(2):223-230, 2015.

MANTOVANI, E. C. Compactação do solo. Informe Agropecuário, 13(147):52-55, 1987.

MARTINS, P. C. C. et al. Levels of induced and compaction as caused by forest harvesting operations. Cerne, 19(1):8391, 2013.

MOSADDEGHI, M. R. et al. Plate sinkage versus confined compression tests for in situ soil compressibility studies. Biosystems Engineering, 93:325-334, 2006.

PAIS, P. S. M. et al. Load-bearing capacity of a red-yellow latosol cultivated with coffee plants subjected to different weed managements. Ciência e Agrotecnologia, 37(2):145-151, 2013.

PEZZONI FILHO, J. C. et al. Compactação de um Cambissolo Háplico causada pela extração florestal com trator skidder. Cerne, 20(2):199-208, 2014.

SANTOS, H. G. et al. Sistema brasileiro de classificação de solos. 3.ed. rev. e ampl. Brasília: Embrapa, 2013a. 353p.

SANTOS, R. D. et al. Manual de descrição e coleta de solo no campo. 6.ed. rev. e ampl. Viçosa: Sociedade Brasileira de Ciência do Solo, 2013b, 100 p.
SEVERIANO, E. C. Preconsolidation pressure, soil water retention characteristics, and texture of Latosols in the Brazilian Cerrado. Soil Research, 51:193-202, 2013.

SILVA, A. R.; DIAS JUNIOR, M de S.; LEITE, F. P. Camada de resíduos florestais e pressão de preconsolidação de dois latossolos. Pesquisa Agropecuária Brasileira, 42(1):8993, 2007.

SILVA, A. R.; DIAS JUNIOR, M. de S.; LEITE, F. P. Propriedades físicas e mecânicas de latossolos em diferentes manejos florestais. Ciência e Agrotecnologia, 34(6):1483-1491, 2010.

SILVA, A. R.; DIAS JUNIOR, M. S.; LEITE; F. P. Avaliação da intensidade de tráfego e carga de um forwarder sobre a compactação de um Latossolo Veremlho-Amarelo. Revista Árvore, 35(3):547-554, 2011.

SNEDECOR, G. W.; COCHRAN, W. G. Statistical methods. 8. ed. Iowa State University Press. 1989, 503p.

SOIL SURVEY STAFF. Soil taxonomy: A basic system of soil classification for making and interpreting soil surveys. 2 ed. Washington: Natural Resources Conservation Service, 1999. 169p.

SUZUKI, L. E. A. S. et al. Estrutura e armazenamento de água em um Argissolo sob pastagem cultivada, floresta nativa e povoamento de eucalipto no Rio Grande do Sul. Revista Brasileira de Ciência do Solo, 38: 94-106, 2014.

SZYMCZAK, D. A. et al. Compactação do solo causada por tratores florestais na colheita de Pinus taeda L. na região sudoeste do Paraná. Revista Árvore, 38(4) 641-648, 2014.

TAYLOR, D. W. Fundamentals of soil mechanics. New York, John Wiley \& Sons, Inc., 1948. 700p.

VISCHI FILHO, O. J. et al. Capacidade de suporte de carga de Latossolo Vermelho cultivado com cana de açúcar e efeitos da mecanização no solo. Pesquisa Agropecuária Brasileira, 50(4)322-332, 2015. 